INTER NATIONAL MONETARY FUND

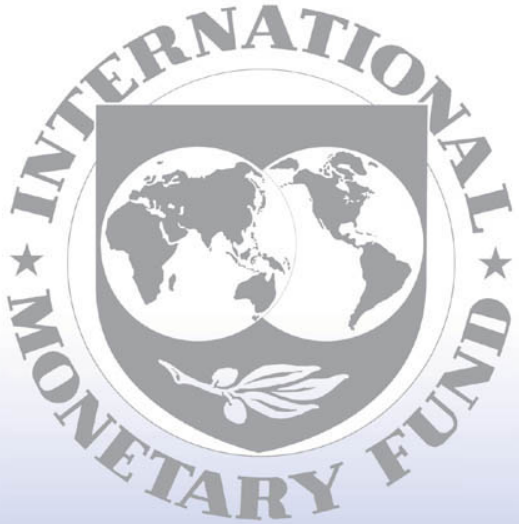

Staff

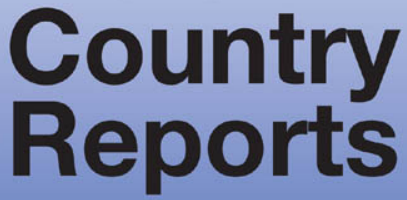




\section{Cape Verde: Poverty Reduction Strategy Paper-First Annual Progress Report}

Poverty Reduction Strategy Papers (PRSPs) are prepared by member countries in broad consultation with stakeholders and development partners, including the staffs of the World Bank and the IMF. Updated every three years with annual progress reports, they describe the country's macroeconomic, structural, and social policies in support of growth and poverty reduction, as well as associated external financing needs and major sources of financing. This country document for Cape Verde, dated May 2006, is being made available on the IMF website by agreement with the member country as a service to users of the IMF website.

To assist the IMF in evaluating the publication policy, reader comments are invited and may be sent by e-mail to publicationpolicy@imf.org.

Copies of this report are available to the public from

International Monetary Fund • Publication Services

$70019^{\text {th }}$ Street, N.W. $\bullet$ Washington, D.C. 20431

Telephone: (202) 623-7430 • Telefax: (202) 623-7201

E-mail: publications@imf.org •Internet: http://www.imf.org

Price: $\$ 15.00$ a copy

\section{International Monetary Fund}

Washington, D.C. 
This page intentionally left blank 


\section{MINISTRY OF FINANCE AND PUBLIC ADMINISTRATION GENERAL PLANNING DIRECTORATE}

IMPLEMENTATION OF THE GROWTH AND POVERTY REDUCTION STRATEGY CAPE VERDE

\section{REPORT}

2006

May 2006 - DGP 


\section{TABLE OF CONTENTS}

\section{BACKGROUND FOR STRATEGY IMPLEMENTATION}

$>$ Review of Objectives and Key Expected Outcomes

$>$ Monitoring Mechanisms

II. OVERALL IMPLEMENTATION

$>$ Budget

1. Medium-Term Sectoral Expenditure Framework

2. Budget Procedures

3. Procurement of Goods and Services

$>$ Tax and Customs Reform

$>$ Public Finance

$>$ Monetary Policy

\section{IMPLEMENTATION OF STRUCTURAL REFORMS}

$>$ Reform of the Administration

$>$ Privatization of Companies

$>$ Reform of the Judiciary System

$>$ Reform of the Social Protection System

\section{SECTORAL IMPLEMENTATION}

V. ANNEX - Tables 


\section{ACRONYMS AND ABBREVIATIONS}

\begin{tabular}{|c|c|}
\hline ACRONYM & NAME \\
\hline $\mathrm{ADB}$ & African Development Bank \\
\hline ANMCV & $\begin{array}{c}\text { Associação Nacional dos Municípios de Cabo Verde [National Association of } \\
\text { Municipalities of Cape Verde] }\end{array}$ \\
\hline ANSA & Agência Nacional de Segurança Alimentar [National Food Security Agency] \\
\hline ARFA & $\begin{array}{c}\text { Agência de Regulação e Supervisão de Produtos Farmacêuticos e Alimentares [Food } \\
\text { and Drug Regulation and Supervision Agency] }\end{array}$ \\
\hline $\mathrm{BCV}$ & Bank of Cape Verde (Central Bank) \\
\hline CFAA & Country Financial Accountability Assessment \\
\hline $\mathrm{CM}$ & Municipal Council \\
\hline CNSA & Conselho Nacional de Segurança Alimentar [National Food Security Council] \\
\hline CPAR & Country Procurement Assessment Review \\
\hline DGAL & Direcção Geral de Administração Local [General Local Administration Directorate] \\
\hline DGCI & Direcção Geral de Contribuição e Impostos [General Tax Directorate] \\
\hline DGO & Direcção Geral do Orçamento [General Budget Directorate] \\
\hline DGOTH & $\begin{array}{c}\text { Direcção Geral de Ordenamento de Território e Habitação [General Land } \\
\text { Management and Housing Directorate] }\end{array}$ \\
\hline DGP & Direcção Geral do Planeamento [General Planning Directorate] \\
\hline DGPE & Direcção Geral do Património do Estado [General State Assets Directorate] \\
\hline DGSS & Direcção Geral de Solidariedade Social [General Social Solidarity Directorate] \\
\hline DSSA & Direcção de Serviços de Segurança Alimentar [Food Security Services Directorate] \\
\hline IBE & Integrated Basic Education \\
\hline EIA & Environmental Impact Assessment \\
\hline FADM & $\begin{array}{l}\text { Fundo Autónomo do Desenvolvimento Municipal [Autonomous Municipal } \\
\text { Development Fund] }\end{array}$ \\
\hline FAO & Food and Agriculture Organization \\
\hline FEF & Fundo de Equilíbrio Financeiro [Financial Balance Fund] \\
\hline GEP & Gabinete de Estudos e Planeamento [Sectoral Analysis and Planning Office] \\
\hline GPS & Geographic Positioning System \\
\hline ICASE & $\begin{array}{c}\text { Instituto Cabo-verdiano Acção Social Escolar [Cape Verdean School Social Action } \\
\text { Institute] }\end{array}$ \\
\hline IFIs & International Financial Institutions \\
\hline INAG & $\begin{array}{l}\text { Instituto Nacional de Administração e Gestão [National Administration and } \\
\text { Management Institute] }\end{array}$ \\
\hline M\&E & Monitoring and Evaluation \\
\hline
\end{tabular}




\begin{tabular}{|c|c|}
\hline MAAP & $\begin{array}{c}\text { Ministério do Ambiente, Agricultura e Pescas [Ministry of Environmental Affairs, } \\
\text { Agriculture and Fisheries] }\end{array}$ \\
\hline MCA & Millennium Challenge Account \\
\hline $\mathrm{MCC}$ & Millennium Challenge Corporation \\
\hline MREAP & $\begin{array}{l}\text { Ministério da Reforma do Estado e Administração Pública [State and Public } \\
\text { Administration Reform Ministry] }\end{array}$ \\
\hline MTEF & Medium-Term Expenditure Framework \\
\hline NIF & Número de Identificação Fiscal [Tax Identification Number] \\
\hline NOSI & $\begin{array}{c}\text { Núcleo Operacional para Sociedade da Informação [Information Society Operational } \\
\text { Nucleus] }\end{array}$ \\
\hline PCCS & Plano de Cargos, Carreiras e Salários [Posts, Careers and Salaries Plan] \\
\hline PESA & Programa Especial de Segurança Alimentar [Special Food Security Program] \\
\hline PESI & $\begin{array}{c}\text { Plano Estratégico para a Sociedade de Informação [Strategic Plan for the Information } \\
\text { Society] }\end{array}$ \\
\hline PMM & Plano de Modernização Municipal [Municipal Modernization Plan] \\
\hline PNLP & Programa Nacional de Luta contra a Pobreza [National Poverty Reduction Program] \\
\hline PNSA & Programa Nacional de Segurança Alimentar [National Food Security Program] \\
\hline PRGS & Poverty Reduction and Growth Strategy \\
\hline PRSP & Poverty Reduction Strategy Paper \\
\hline PSM & Pensão Social Mínima [Minimum Social Pension] \\
\hline PSS & Pensão de Solidariedade Social [Social Solidarity Pension] \\
\hline RDP & Public Expenditure Review \\
\hline SEN & Sistema Estatístico Nacional [National Statistical System] \\
\hline SIGOF & Sistema Integrado de Gestão Orçamental [Integrated Budget Management System] \\
\hline SISA & Sistema de Informação para Segurança Alimentar [Food Security Information System] \\
\hline STAD & $\begin{array}{c}\text { Secretariado Técnico de Apoio ao Desenvolvimento [Technical Secretariat for } \\
\text { Development Support] }\end{array}$ \\
\hline WFP & World Food Program \\
\hline WTO & World Trade Organization \\
\hline
\end{tabular}




\section{BACKGROUND FOR IMPLEMENTATION}

This is the first year (2005) of the Poverty Reduction and Growth Strategy (PRGS). More than to provide a background for the implementation of the Strategy, this chapter seeks to review the Objectives and Key Outcomes and to report on the status of the Strategy Implementation Monitoring Mechanism.

The implementation occurred under a macroeconomic environment of stability with a high level of participation. The scenario for the three-year PRGS implementation period points to a 6.5-percent average annual rate of economic growth, which is considered to have been reached in 2005 (GDP grew at around 6 percent, driven by private and public investments and a recovery in the export sector), and inflation under control at 0.4 percent. International reserves grew to nearly 3.2 months of imports of goods and services in late 2005 . There was a favorable improvement in the overall balance of payments in 2004 and 2005 (at around 3 percent of GDP).

In short, the economy is thought to be stable. The Government is determined to continue this performance, thus indicating to the international community that it is committed to maintaining solid economic policies. The strategy focuses on the implementation of various government programs for poverty reduction. A Credit Agreement (PRSC) signed in January 2005 ensured funding for the implementation.

The preparation of this first annual report on the implementation of $\mathrm{PRGS}_{2005}$ requires preliminary work to be performed in gathering and updating outcome indicators and finalizing the process of validating goals that are consistent with the initial data from 2004 and with the objectives of the PRSP. Such work is in progress. The Technical Secretariat for Development Support (STAD - Secretariado Técnico de Apoio ao Desenvolvimento) is responsible for the preparation of this report with the support of Theme Groups that are not active yet. The entity is fully open to receiving technical assistance for the preparation of the PRSP implementation report through the STAD.

$>$ Review of Objectives and Key Expected Outcomes

The Strategy's goals are organized around five (5) major strategic aims whose purpose is to focus greater attention on poverty reduction and growth policies. The Strategy implementation is subject to a three-level plan based on objectives (1. Strategic Aim; 2. Strategic Sub-aim; and 3. Priority Measure).

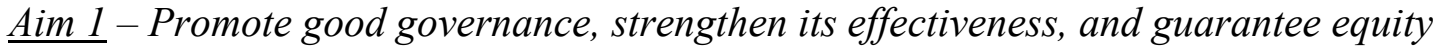

The objectives under this aim pertain to (i) setting up and maintaining an efficient and transparent budgetary management system; (ii) strengthening management capacity and economic performance; (iii) reforming and modernizing government administration; and (iv) improving justice system operations.

The expected outcomes from (i) are related to: determining the indicative budgetary ceilings for each ministry; knowledge of the taxpayers; modernization of the Information Technology 
(IT) system; establishment of a quarterly schedule of payments; conversion of existing protocols into Treasury Bonds and Treasury Bills; draft law creating the Financial Comptroller; Parliament's adoption of the Decentralization Framework Law and the Local Finance Law; delivery to Parliament of Legislation on the reorganization and jurisdiction of the Comptroller General and the financial autonomy of the IGF; adoption of the Law and procedures for government procurement; and implementation of the technical unit.

The expected outcomes from (ii) are related to: finalizing the Social Scoreboard and the follow-up survey on poverty and approving the Statistical Agenda; preparing this report and the Medium-Term Expenditure Framework (MTEF) report; and implementing the Official Statistics Database (BDEO - Base de Dados de Estatísticas Oficiais) and the STATLINE. With respect to (iii), we are awaiting the establishment of the public sector reform mechanism; the implementation of the civil-servant database; the diagnostic of human resources; a Government Administrator (for the budgeting, human resources, and administrative reform areas) in each ministry. With respect to objective (iv), we are waiting for the National Assembly to adopt the laws drafted to facilitate the guarantee of legal aid for the poor and for the establishment of alternate mechanisms to resolve conflicts and raise public awareness of issues related to the rule of law.

\section{$\underline{\text { Aim } 2}$ - Promote competitiveness in order to boost economic growth and job creation}

The objectives pertain to (i) promoting and developing tourism; (ii) promoting and consolidating the domestic business sector; (iii) promoting competitiveness and growth, and expanding the productive base; (iv) reorganizing and developing Fisheries; and (v) modernizing the agricultural sector and developing the rural sector.

Overall, the key expected outcomes relate to (strategic) planning, training, capacity building and support for private agents in developing infrastructures (industrial park) and managing forest areas. More specific outcomes refer to the review and publication of fisheries legislation as well as the control over the quality of food and the dissemination of technological packages and inspection.

\section{$\underline{\text { Aim } 3}$ - Develop and enhance human capital}

Very briefly, the objectives defined here pertain to (i) modernizing and expanding the educational system; (ii) building a national employment and training evaluation system; (iii) population and development; (iv) promoting employment; and (v) reforming the health system.

The key expected outcomes relate to providing school infrastructure and equipment at all educational levels, particularly in the rural areas, and training and developing the capacity to use information and communication technology (ICT). Review of programs, curricula, and textbooks. Technical training is revitalized at the secondary level and appropriate legislation is developed for the university level.

School health at the Integrated Basic Education (IBE) level includes all teachers and children. School social support is expanded to cover all needy children. The employment and 
professional training network is extended to all municipalities and the generation of statistics is reinforced. The new national population policy is validated but will require approval from the Council of Ministers. With respect to employment, the start of microenterprises is encouraged and training targeted to specific areas is developed.

The reinforcement and expansion of health structures, in addition to the implementation of the Priority Programs, will allow improvements to be introduced in various areas, e.g., vaccination, HIV/AIDS prevalence stabilization and mortality rate, as well as wider and better access to healthcare in the country. Another expected outcome is better health system management through the improvement of the health information system.

Aim 4 - Improve and develop basic infrastructures, promote land management, and conserve the environment.

The objectives refer to (i) land management and urban planning; (ii) environmental protection and conservation; (iii) promotion and reinforcement of Sanitation; (iv) energy development; and (v) development of transportation infrastructures.

The key outcomes are related to legislation, planning, and information system development, map production (as part of land management and urban planning), and technical training and development. The outcomes in the area of the environment include decentralized management, increased water supply coverage, greater protection for resources, and the implementation of the information system (geographic, environmental, and territorial).

In sanitation, the expected outcomes include the expansion of water supply, wastewater treatment and reuse, solid waste collection, and construction start for three (3) landfills. In energy, the outcome is the expansion of rural electrification. The development of transportation infrastructures has resulted in the construction of access roads to remote locations and the improvement of ports and roads in some islands.

Aim 5 - Improve the social protection system, strengthen its effectiveness, and guarantee its sustainability

The objectives established for this aim refer to (i) social protection, integration, and insertion; (ii) protection of children's rights; (iii) food guarantee and security for the population; and (iv) adjustment and rebalancing of housing promotion.

The key outcomes are decentralization process regulation for social protection services, agent training, pension management through the identification and increase in the number of beneficiaries, and greater access to healthcare and medications, education and professional training, water, sanitation, housing, and food for the poor. Another expected outcome is technical training and planning for specific social areas.

In terms of food security, the decentralized FS information system becomes operational and improves FS management, private sector participation in food supply, and the regular market operation. Technical capacity and the ability to intervene in the institutions involved with food quality are strengthened and consumer protection associations begin to appear. A 
permanent and effective mechanism for monitoring the nutritional situation nationwide is created.

The outcome sought in protecting children's rights is greater coverage and access to social equipment in all municipalities, training of families and agents, as well as NGOs and CSOs working with the underaged.

In the area of housing, we are awaiting the promotion of the social housing program and support for needy families in home construction and rehabilitation.

Overall Monitoring and Evaluation (M\&E) Mechanism

The development of an M\&E mechanism for Strategy implementation is key to identifying the outcomes, measuring progress, adjusting goals, and maintaining donors and the Government informed about economic growth, poverty, vulnerability, inequalities, and the impact of growth and poverty policies and programs. M\&E is essential for a successful implementation of the PRSP. It allows implementation reports to be prepared for donors that provide budget support.

However, in addition to the traditional monitoring mechanisms based on the data made available by the official National Statistical System organizations, qualitative and participatory methods are expected to be strengthened to provide information on and indicators of the population's living conditions, changes and perceptions from various program beneficiaries.

PRSP M\&E (implementation of structures, data gathering, flow of information among sectors, the INE, and the STAD) has shown little progress. There are signs of difficulties and, therefore, the need is clear not only for outside support but also for improvements at the organizational level, such as properly structured units, an adequate management system, motivated human resources, and the capacity to execute in accordance with assigned duties, as observed/noted by various partners/donors.

M\&E is based on genuinely needed and reliable official quality statistics made available on a timely manner and at an appropriate cost, to meet operating and decision-making management requirements. The availability of reliable statistics is linked to the Training Plan developed in 2005 and the improvements made to the National Statistical System and the information system, with indicators that allow gains and losses in poverty conditions to be monitored with the IT developed by the NOSI.

The overall evolution of the monitoring and evaluation system indicates the following:

The Official Statistical Database, the BDEO, developed by INE, is not yet completed. If resources are provided for the QUIBB survey on a timely basis, the INE undertakes to provide the data for the preparation of the first PRSP report.

The initiative to establish a database to monitor public PRSP programs and projects, including entry, activity, exit, and result indicators (BDMP/DGP), in close cooperation with the sectors, is urgent and cannot be delayed. Cooperation to choose the sectoral programs and areas 
(GEP/DGPOG), the NOSI (for the IT area), and the DGO (for the budget area). Although the connections are working internally, the implementation of a pilot satellite database sector has not yet been completed.

> The Technical Secretariat for Development Support (STAD - Secretariado Técnico de Apoio ao Desenvolvimento) is still without a coordinator despite the publication of its organizational chart on the Official Gazette, and the lack of qualified human resources has been impeding the proper performance of assigned duties.

> The need for training local staff persists (sine qua non condition), namely in the areas of monitoring and evaluation, management based on results, data analysis, as well as development and maintenance of a database.

The institutional framework designed to monitor the implementation of the strategy is based on existing administrative structures, functionally adapted as deemed appropriate. The National Council for Poverty Reduction is a consultative body that includes key partners from government, the private sector, and civil society. For planning purposes at the central level, the MFAP General Planning Directorate (DGP) provides coordination and technical support through the STAD. The Ministerial Analysis and Planning Offices (GEPs) serve as technical units for preparation and monitoring/evaluation of the strategy's priority programs and projects. At the local level, the Regional Poverty Reduction Councils are consultative in nature.

PRSP implementation and monitoring require technical assistance and support for several Ministries. It is crucial for the Government to carefully evaluate such needs, particularly with respect to the priority measures, and to establish a technical assistance plan (including costs, terms of reference, and possibly allocation of resources). Some of the assistance funds provided by the European Commission (EC) in the past were not fully used during their periods of availability.

The progress made in setting up the FS system is below expectations. The Technical Secretariat for Development Support (STAD) was created to strengthen the DGP in its function as PRSP coordinator, but inadequate resources affected the efficiency of the STAD. It is crucial that adequate resources be allocated to the different M\&E teams and that their institutional insertion be completed following the PRSP. 


\section{OVERALL IMPLEMENTATION}

Cape Verde has experienced a solid pace of growth during the 2001-2005 period, with average rates of economic growth of around 5.8 percent, low inflation rates, and a reduction in absolute poverty. Despite this performance, the country faces enormous development challenges related essentially to unemployment and relative poverty, which continue to be at high levels, inadequate infrastructures, and the need to improve public and other services that support sustained growth.

\section{$>$ Public Finance}

Public finance reform is a key condition for budget support to become available and for sound financial management and use of resources for sustained economic growth. The government is implementing a set of reforms to make the public and financial management system more efficient, reliable, and transparent. A set of measures is being developed for the implementation of the recommendations resulting from the public expenditure review conducted under the Country Financial Accountability Assessment (CFAA) and the Country Procurement Assessment Review (CPAR) projects.

The new Public Finance model under implementation will allow clearer priorities to be set, guarantee improvements in the public-policy adoption process and accelerate the decisionmaking process, introduce enhancements to the management method based on objectives that are easily measurable and evaluated through impact and outcome indicators. Moreover, it will allow greater integration of information, more transparency, and participation and accountability mechanisms for public administrators. Further adjustments to policies and programs will also be possible based on the achieved outcomes.

The CFAA Project has turned out to be an important tool to coordinate the implementation of Financial Management Reforms. It is important to implement, coordinate, control, and monitor public finance management agenda activities. Some delays reported in this chapter are a cause for concern.

The achieved outcomes refer to the development of an action plan (11/2005) for the 2004-07 period. A CFAA implementation cell has been coordinating and the Steering Committee has been monitoring the implementation of the AP's priority measures. However, the implementation of the CFAA and CPAR AP's integrated measures must be better coordinated and a greater national financial contribution for the public finance management reforms must be provided in the general government budget.

The implementation of the AP has given continuity to the policies of budgetary and fiscal consolidation, improved resource mobilization capacity, particularly in the budget support area, as well as built institutional capacity in financial management, with concrete reflections in the process and the integrated budgetary and financial management system (SIGOF Sistema Integrado de Gestão Orçamental e Financeira).

With the implementation of the CFAA AP and the availability of the SIGOF, it is easier to control the implementation, conduct inspection activities, and render accounts in real time. 
This increased the ability of the various organizational units to prepare, execute, and monitor the budget.

In terms of rendering of accounts and reporting, there has been progress in the preparation of public accounts and a decrease in delays. The general government accounts for 2000-2003 were completed and the 2000-2002 accounts were transmitted (current practice) to Parliament as planned. The quarterly budget execution report is available on the MFP website.

The Public Accounting Office has forwarded a draft law to the various partners for discussion. Internal MFP approval had not come through as planned by late October 2005, pushing the approval by the Council of Ministers to 2006, when the new nomenclature (used by the SIGOF) will be implemented.

A set of financial actions and tools was developed for financial rigor and discipline, and to improve the management, consolidation and control of public accounts. The implementation of these actions and tools provided for greater integration of the current information system, which is essential for sound management, control and quick decision making in budgeting and finance, with respect to budget and finance, assets, and contingencies.

In order to establish a new paradigm of sound Public Finance management in planning as well as budgetary, financial, and fiscal management, the Budgetary and Financial Management System (SIGOF) must be appropriated and its use must be expanded to the entire PA through training activities and the adoption of procedures manuals. One important challenge to face is the integration of the components for asset management and accounting as well as procurement management for goods, services, and public works into the SGIOF, as well as the integration of the SYDONIA++ system and the development of the entire Planning, Monitoring, and Evaluation component per commitments undertaken with our partners.

$>$ Budget

Implementation is underway for the recommendations resulting from the Public Expenditure review activities, which revealed the key weaknesses of the budgeting exercise. The vast work related to the Review of Public Expenditures produced reports on the priority sectors in Education, Health, and Agriculture.

The year of 2005 is in a pre-elections period. The budgeting activity for 2006 was prepared by the DGO but its presentation to Parliament was delayed. As a result, the Decree-Law pertaining to the 2005 budget execution remained in effect until the new Parliament approved the 2006 budgetary law. Consequently, a budget rectification was drafted (in June/July 2005) with the participation of all organizations involved in the planning system. But such budget did not contemplate the amount of subsidies for gas stations and thus compromised the expenditure/debt reduction effort that the Government has promoted for several years. 
At the same time, the Implementation Balance and the Implementation Report for the 2004 Investment Program was finalized on the basis of the disbursements made by the National Treasury, based on the SIGOF, the Treasury's Foreign Debt services, and reports from direct financiers as the main sources of information.

\section{- Medium-Term Expenditure Framework}

As of 2005 (October), the National Budget started to include, even if provisionally, an overall Medium-Term Expenditure Framework and a set of (4) Medium-Term Sectoral Expenditure Frameworks for the priority ministries. The purpose of these frameworks is to better reflect the growth and poverty reduction policies and their multi-year approach (3 years).

The MTEF introduces objective criteria for allocating and rationalizing public resources as well as improves technical and transparency procedures in managing resources. The overall MTEF and the sectoral MTEF are likely to be combined in the future in order to ensure that the sectoral actions are reflected in the general budget.

This step was expected to be taken as of the 2005 Budget but there was a delay. Finalized sectoral Medium-Term Expenditure Frameworks are not available yet. The development of the $\mathrm{MTEF}_{2005-2007}$ has received technical support from the IDEA Internacional consulting firm. In the meantime, an Overall $\mathrm{MTEF}_{2006-2008}$ Plan is under development, based on the existing preliminary $\mathrm{MTEF}_{2005-2007}$ as well as the macroeconomic projections from the IMF and the priorities established in the PRSP.

The four QDS-MP development activities revealed difficulties related to human resources and inadequate technical training to conduct the activities. The activities require an approach "based on an evaluation of outcomes," which implies organizational changes and behaviors that are not yet in place. Task Forces were established to develop and monitor the implementation of the QDS-MP as a permanent activity.

With respect to the Health MTEF, the WHO may ensure local capacity building and technical sustainability with long-term consultants. The WHO is a crucial partner for the country, particularly for the Credit Agreement, in light of its involvement in key areas of public health.

\section{○ Budget Procedures}

With the country's exclusion from the group of least developed countries, there will be a need to strengthen its internal sources of funding. Multilateral aid shifts to direct support for the national budget, with a global or sectoral focus, while direct aid to projects becomes secondary.

Budget support is more demanding in terms of periodic rendering of accounts and transparency in management and responsibilities. It thus introduces changes in accountability. The outcomes indicate the need to create specific mechanisms and 
procedures, and to increase the level of responsibility for the budgetary management itself and for sectoral policies. Other required changes refer to the legal framework.

As the budgeting process is modernized and the State's new financial regime is implemented, the following outcomes are expected:

- A New National Public Accounting Plan, which establishes an accounting system based on internationally accepted accounting principles.

- The completion of a draft for the Basic Laws for the Budgetary Framework and Planning System, and its approval by the Council of Ministers.

The procedures and IT tools developed through the SIGOF include the following:

- Unification of the National Budget Directives, integrating the operating and investment budget into the new Budget Program approach framework;

- Establishment and designation of Budgetary Ceilings for sectors and Ministries based on the priorities defined in the Medium-Term Expenditure Framework;

- Development of uniform map models and forms for Budget preparation based on a multi-year perspective;

○ Introduction of a "Budgetary Check" mechanism to improve the process of negotiating, mediating, managing and allocating budgetary credit;

- Preparation of Procedures Manuals for the planning system and for Budget preparation at the SIGOF; and

- Combination of the Salary Processing Database and the Human Resources Database to ensure the integration of the technical and financial HR management in the PA.

The new budgetary management model designates responsibilities to the sectors, thus helping to enhance financial management effectiveness and public administrators' accountability. Budget execution is decentralized under the law that establishes the skills and functions of new actors in the financial system and public accounts - Expenditure Authorizing Officer and Financial Comptroller. The law is yet to be regulated. These entities are responsible for coordinating and overseeing the entire budget execution and financial management process.

In the meantime, sectoral ministries obtain access to the budget execution control process through the integrated budget and financial management system, but are limited to reading. The duly credentialed users lack training. Control currently remains with the DGO.

With respect to tax collection and for the purpose of reducing collection costs, a protocol agreement between the DGCI and domestic financial institutions was signed in October 2005 , opening the possibility of an expansion in financial intermediation to include more 
institutions. This measure is provisional and will expire with the establishment of the required conditions at the Department of the Treasury.

The DGCI completed the process of identifying taxpayers and continues to update the taxpayer identification number (NIF - número de identificação fiscal) files.

\section{Procurement of goods and services (DGPE)}

Procurement of goods and services by the government is being restructured. Efforts are underway (started in 2005) to extend the Government Procurement Law and harmonize procedures. The sectoral diagnostics resulted in a strategic action plan for implementation of the National Procurement and Public Market System, based on internationally recognized procedures. The Millennium Challenge Corporation (MCC) in the United States proposes to fund some of the CPAR action plan activities, namely the future Procurement Code, training, and the implementation of a modern e-procurement information and management module and its respective website as part of the SIGOF.

In an initial phase, the project will include the components and sectors financed under the MCA program (Finance, Infrastructure, Agriculture, and Economy). In the second phase, it will be extended to the entire Central Administration. Subsequently it will include the Public Institutes and, in the fourth and final phase, the Municipal Councils.

\section{$>$ Tax and Customs Reform}

In terms of legislation and with technical support from the International Monetary Fund (IMF), several instruments were enacted, including:

Decree-Law - Establishment of the VAT Directorate

Decree-Law - Regulation for VAT Payment and Reimbursement

Decree-Law - Application of VAT to Prices Charged

Decree-Law - Establishment of the Regime for Civil Construction Contracts and Contracts Entered Into by Tourism Operators Prior to January 2004

Decree-Law - Special Regime for Tourism Operator Agencies

The implementation of the Expenditure Taxation Reform program modernized taxes and customs duties. As a consequence, the number of import fees and duties was reduced with the elimination of some taxes and the "Emolumentos Gerais" import duty. This left a single customs tax: the Import Duties.

The modernization of the Tax Collection and Payment Method System will provide for greater control and efficiency in tax collection. The "Tax Collection, Payment, and Reimbursement" Decree-Law was enacted in order to ensure greater functionality and efficiency in tax-revenue collection and to offer alternative methods for tax payments through other banking institutions and new collection and service counters.

A new tax withholding regime was approved, yielding positive results, with the adoption of a new calculation method for withholdings, which clearly benefits lower-bracket taxpayers and 
ensures greater financial availability for lower-income families. This method also brought better alignment and greater realism between withheld and applicable taxes. Another project is also under implementation to improve service at the various Tax Offices. This strategy is expected to improve the quality of services rendered at the tax offices, with a guarantee of a closer contact with the taxpayers.

The Tax Exemption policy was reviewed with respect to costs/benefits and sectors that are strategic for economic and social development. This review yielded a proposal for the adoption of a specific instrument to define the bases for tax benefits, which will regulate the entire legal framework and regime, from projecting to granting and controlling tax benefits.

Roll of Taxpayers - The roll of taxpayers is one of the tax reform's priority measures. The database for the Roll of Taxpayers is currently being consolidated. With the introduction of the new taxpayer identification numbers (NIF) and the computer system's automatic cancellation of repeat numbers, the new roll of taxpayers will provide for a significant improvement in the management and control of the taxpayer's fiscal situation, particularly with respect to VAT. A computerized management application was thus developed for the issuance of the Taxpayer ID, which will considerably enhance the services provided to taxpayers.

Tax and Customs Enforcement and Government Inspection - The tax administration undertook tax enforcement actions to collect debts, which had a positive impact on revenues and encouraged taxpayers to meet their tax obligations. The tax apparatus has considerably improved its enforcement activities, specifically with respect to the internal analysis of income (IUR) taxpayers, in the process of establishing collectibles, as well as its external analysis, which has already started, with the tax audits of some Companies subject to the verification method. This is a program that will likely be expanded and continued until the end of the year.

Customs Legislation - The outcomes include a new Schedule of Tariffs. The Cape Verdean Customs Code, after its adoption, will constitute a modern body of laws that is systematically structured according to international standards and recommendations governing customs activities.

IT Management - The outcomes include the introduction of the new SYDONIA++ system at all customs levels, with significant benefits for customs services. This system required the creation of a national communications network, the adaptation of some customs regulations, particularly the new clearance form (DAU - Declaração Aduaneira Única) and the new customs and statistical regime coding, the acquisition and installation of computer equipment and their respective software applications.

Training on SYDONIA++ was also provided, nationally, to all customs officers and other users (official agents, transportation companies, and other partners in customs administration). 
Internal Audit - Significant improvements were achieved. The Office of the General Inspector of Finance (IGF - Inspecção Geral das Finanças), as part of its enforcement role, was very active in preventing behaviors that are contrary to the public interest and in the timely detection of legal or staff inadequacies. The improved efficiency in preventing financial and institutional illegality, in order to preserve and improve the technical quality of its work, was a result, to some extent, of the adoption of new statutes and procedures, the increase in staff, and the acquisition of computer equipment, which strengthened the capacity of the institution.

The enactment of the Charter Law and the Statute of Personnel for the IGF, two (2) important intervention instruments, is an important landmark. The Statute of Personnel allowed the IGF to monitor its reports at the other control institutions, such as the Comptroller General, the Office of the General Prosecutor of the Republic, the Judiciary Police, etc.

With the material support (computer equipment) from the CFAA Project, the IGF became more viable in 2005. Its inspection capacity grew significantly with the recruitment and subsequent training of seven (7) new inspectors. Thus, as of 2004, the IGF efforts intensified, with more inspections, narrow audits, and account reports on the Dutch Budgetary Support and the MCA Funds.

The preparation of some Methodology Manuals or Guidance Scripts for inspections and the compilation of the Legislation Systematization are other outcomes produced as part of the IGF activities. These actions had an impact on the speed of information query (database created) and the performance of inspectors. However, the IGF requires more training activities and is seeking support from the CFAA Project for this area, which is considered indispensable for its inspectors' ability to intervene and monitor technical aspects.

In terms of adjustments, the IGF now orients and frames its activities under an Annual Plan of Activities and focuses on the generation of Activity Reports, giving a lesser priority to narrow or occasional actions. In terms of external audits, it is important to note that the Comptroller General has already reviewed the General Government Accounts for 1998 and 1999 and is reviewing the GGA report for 2000. The GGA for 2001 and 2002 are awaiting review by the CG. The CG needs to recruit more personnel in order to build its capacity to intervene as well as reduce the delays in auditing the GGA. Portugal is the right partner to provide adequate technical assistance to the Cape Verdean CG.

With respect to training, the nucleus of the CFAA has been helping the CG with training sessions on auditing and capacity-building actions at the workplace in some Municipalities. The Institutional Development Credit Fund is expected to be signed by the World Bank and to start operations in late November 2005, thus creating the conditions for a significant expansion in training requests.

The IGF, the Comptroller General, and the Office of the General Prosecutor of the Republic collaboratively proceeded to complement and coordinate their actions. This situation has 
translated into savings in resources and efforts. These actions greatly increase the credibility of both internal and external audit institution interventions.

The difficulties found in carrying out fiscal policies are related to the treatment given to conditional liabilities (this is the object of a specific study), particularly to the preparation of a plan for its resolution. There was limited progress in 2005. The Public Treasury continues to review the debts that were identified in order to determine whether they should be recognized or not. A schedule of payments has been established for part of the debt but no plan has been developed to avoid a renewed build-up of liabilities, nor any plan (scheduling, attribution of responsibilities, and sources of financing) to resolve the conditional liabilities and the debts.

In order to exercise stricter fiscal control, the Public Treasury will no longer cover excess salary expenditures incurred by the education and health sectors as a result of staff hires beyond budget limits.

Monetary Policy

With respect to monetary policy, the Government continues to maintain the foreign exchange agreement and the European zone currency as a peg to control inflation.

\section{Financial System}

Financial services are experiencing accelerated growth. Recent developments include the ongoing establishment of a centralized credit bureau to evaluate borrower creditworthiness, thus furthering access to credit and the culture of credit in general.

In the banking sector, offshore banks were developed ( 4 banks in operation; 4 other offshore banks and 2 parabanking institutions were licensed but are not yet in operation).

Total banking sector assets increased 20 percent since late 2004, reaching more than 90 percent of nominal GDP, with growth strongly concentrated in the construction sector. Immigrant deposits, which account for more than 40 percent of total deposits, continue to play a fundamental role in the banking sector. Profitability in the banking sector was significantly affected in 2005 as a result of a reduction in interest rate spreads and the aforementioned monetary overhang, even if the prudential indicators remain solid. The offshore banking sector, which is in rapid development in Cape Verde, now includes four offshore banks in operation as well as four other banks and two parabanking firms licensed but not yet in operation. Recent developments in the financial sector include an ongoing project to establish a centralized credit bureau to help creditors evaluate borrower creditworthiness, thus furthering access to credit and the culture of credit in general.

Excess bank reserves increased substantially in 2005 due to a strong inflow of capital, the reduction of mandatory reserves, and slower expansion in credit provided to the private sector in the first half of the year. As a response, the Bank of Cape Verde (BCV) proceeded with a sale of bonds to partially absorb excess liquidity. 
In partnership with the domestic Financial Institutions, legal and institutional conditions were established for a Capital Market to operate and to invigorate the Stock Exchange for the purpose of transforming Cape Verde in an international reference financial market. The Cape Verde Stock Exchange is going through a recovery period in its activities and offers daily transactions of Government bonds and shares of a reduced number of companies.

Despite the significant improvements achieved in reforming financial management and modernizing the procedures for budgetary, financial, and fiscal planning, there is still a long way to go. But the government is determined to proceed with the regulation and supervision of financial institutions, including International Financial Institutions (IFI), in accordance with international best practices.

Collaboration and support from the international partners will invigorate and provide continuity to the implementation of the actions and measures yet to be completed. The objective is to shed any attitudes and practices that still persist in financial management and obstruct the course of the positive changes required for a Sound Public Administration.

\section{Local Finance}

The Local Finance Law was enacted as a prerequisite for the Credit Agreement 2 and the distribution criteria were changed for the Financial Balance Fund (FEF - Fundo de Equilíbrio Financeiro), which increased in value.

A draft of the Decentralization Framework Law is currently being prepared.

The Autonomous Municipal Development Fund (FADM - Fundo Autónomo do Desenvolvimento Municipal) has a new legal statute but has not started operations yet as it lacks a Board of Directors and an Executive Director (planned for 2006). The FADM is an instrument to directly channel sectoral budget support from the Netherlands to the Municipalities. The Fund will enhance the financial sustainability of Municipalities (through contributions from the National Budget and other partners).

With respect to the Municipal Fund for the Environment, the municipalities included in the framework of municipal environmental plans have benefited from the financial support provided by the Netherlands, which is channeled through contractual mechanisms programs established with each municipality individually.

The implementation of computerized financial management systems is underway in more than three municipalities (and planned for all municipalities in Santiago, Fogo, and Brava), which benefited from the financial management system proposed by the NOSI. A protocol agreement was signed by the NOSI, the National Association of Municipalities in Cape Verde (ANMCV - Associação Nacional dos Municípios de Cabo Verde), and the DGAL, and the NOSI has already started to evaluate the information technology capacity in the Municipalities to form a basis for its implementation. 


\section{IMPLEMENTATION OF STRUCTURAL REFORMS}

The government is determined to proceed with its agenda of structural reforms. These reforms focus on enhancing capacity and productivity within the limits imposed by the allocated resources.

\section{$\underline{\text { Reform of the Administration }}$}

The Government Administration reform is supported by a validated Strategic Plan to reform the State and Government Administration and a detailed Action Plan to train human resources and build capacity in the area of public finance administration. The developed database of civil servants will provide support for the analysis of the current workforce and the submission of proposals for more relevant reforms in the civil service. The database is centralized at the Public Accounting Office, MFP. The DB is not unified yet, with data from two (2) institutes and the Municipalities yet to be integrated. The Municipalities do not yet have direct access to the database.

The delay in the submission of the General Accounts of the Government was recovered and the reports for 1998-2003 were presented to Parliament. The preliminary quarterly accounts for 2004 and 2005 were also submitted to parliament.

Privatization of Companies - The national airline (TACV) is being prepared for privatization and the bidding process for the privatization of ENAPOR is also going forward.

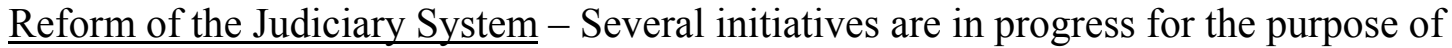
placing the focus of the Justice sector on the citizen and the exercise of citizenship. Thus, the efforts were directed toward removing legislative obstacles and creating the conditions to offer swifter and more efficient justice (by strengthening its administration) to the citizens. The new Penal Code has been in effect since October 2004 and the Code of Penal Procedure became effective in October 2005. The Civil Code has also been drafted. The drafting of the Code of Civil Procedure is at an advanced stage.

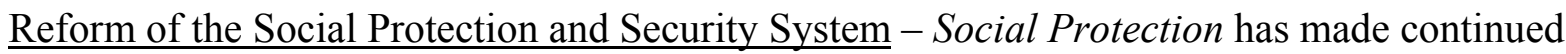
progress but at a varied pace. A Social Protection Development Strategy has been developed and is scheduled for approval by the Council of Ministers in November. The Social Protection reform package includes the finalization of the Social Charter; a study on social pensions and proposals for their reform; a study on and a proposal for decentralizing social protection services at the municipal level.

The proposal to review the protocols for social protection service decentralization should be validated shortly. It should take place in coordination with the enactment of the Decentralization Framework Law, which will provide the overall framework for intervention. According to the PRGS Credit Agreement 2 table, the DGPS signed ten protocol agreements with the NGOs to provide services at the community level, thus freeing the DGPS for coordination and quality control activities. 
Social Pension - As a result of the pension reform process, a partial database of Minimum Social Pension and Social Solidarity Pension (PSM e PSS) beneficiaries is under development, with completion scheduled for late October ( $\pm 40 \%$ completed). The distribution of cards should start between November and December with support from the municipalities. A recent study on the two pension systems recommends that they be combined, which will occur in 2006.

The INPS is reviewing system reform options and the main achievements in the area of financial protection. Priority is given to improving the information system in order to better monitor the social security system and curb fraud.

Children's Rights - The reform efforts in this area have suffered some delays. Some of the planned legal and institutional reviews have not been conducted.

The current status is as follows:

(i) The establishment of a Commission and a Technical Team for Legal and Institutional Reform for matters related to Children and Adolescents and the development of the main instruments of reform;

(ii) The establishment of 3 Municipal Committees for Children's Rights Advocacy (CMDDC - Comités Municipais de Defesa de Direitos da Criança) and one Delegation for Fogo/Brava, with offices in São Filipe;

(iii) The opening of 2 Childhood Emergency Centers (Praia and Mindelo);

(iv) The operation of a Social Reinsertion Center for Women (Santa Catarina Santiago);

(v) The strengthening of two Social Reinsertion Centers (Praia and Picos) and a Children at Risk (Crianças em Situação de Risco) project site (Sal Island);

(vi) The offer of training activities and study visits for personnel working in the area of child and adolescent protection (government institutions and NGOs); and

(vii) The consolidation of the Childhood Emergency (Emergência Infantil) and Education in an Open Environment (Educação em Ambiente Aberto) Programs, with the launch and operation of the following projects: Call, Inform, Foster Family/Shelter (Disque, Denuncie, Família Substituta/Acolhimento) and Support for Homeless Children and their Families (Apoio a Crianças em Situação de Rua e Respectiva Família).

The resources to build technical capacity and provide more materials for the transition centers for minors have been inadequate.

Food Security - The institutional framework for FS includes the National Food Security Agency (ANSA - Agência Nacional de Segurança Alimentar), which is responsible for regulating and guaranteeing the supply of essential food products in the market. The Directorate of Food Security Services (DSSA - Direcção de Serviços de Segurança Alimentar) and the Food and Drug Regulation and Supervision Agency (ARFA - Agência de Regulação e Supervisão de Produtos Farmacêuticos e Alimentares) are the other entities. The National Food Security Council (CNSA - Conselho Nacional de Segurança Alimentar) was created in 2005 to strengthen the institutional framework but has not been regulated yet. 


\section{STRATEGY IMPLEMENTATION AT THE SECTORAL LEVEL}

This chapter lists the sectoral achievements toward the five strategic aims. In practice, each Ministry is responsible for the implementation of the strategy in its respective sector, prioritizing those activities and projects that have the greatest impact on growth and poverty reduction. It also contains a brief description of the monitoring and evaluation mechanisms for the implementation in some sectors.

The institutional framework designed to monitor strategy implementation is based on existing administrative structures, functionally adapted as deemed appropriate. Implementation monitoring in the different sectors allows for implementation reports to be prepared. Sectoral or overall M\&E is based on the availability of reliable statistics as well as implementation, outcome, and impact indicators.

PRSP implementation and monitoring require adequate technical assistance and support, to be detailed in a technical assistance plan and to be channeled to the various M\&E teams, and their institutional insertion after the PRSP.

\section{The M\&E status for the sectoral implementation of the strategy is as follows:}

There is some delay in the implementation of the Monitoring and Evaluation system for the Environmental Action Plan (PANA - Plano de Acção Ambiental). However, there was significant progress in the implementation of the Environmental Information System, which is a key instrument for monitoring environmental quality. The status is as follows: The Environmental Information System is operational through the www.sia.cv portal.

The achievements in the setup of the Geographic/Territorial Information System include the development of the DGOTH website and the architecture for a Geographic/Territorial IS. Software and hardware have been acquired with funding from the Municipal Modernization Plan (PMM - Plano de Modernização Municipal) project's Mapping and Land Registry component. The level of progress is very satisfactory.

Pursuant to the institutional framework for Food Security, the ANSA manages the food market monitoring mechanism, which is part of the Food Security IS (SISA - Sistema de Informação sobre a Segurança Alimentar). The SISA is a fundamental component of food security M\&E with respect to food crisis prevention and management.

With respect to Social Protection, a Social Protection Development and Social Risk Management Strategy was developed. The Strategy includes a proposal to create implementation and monitoring mechanisms. In the current phase, adequate institutional conditions are being established for strategy implementation.

Health care providers are monitoring and evaluating malnutrition and awareness of the correct use of food in the growth and development of children younger than 5 years of age and pregnant women, particularly those from more disadvantaged backgrounds. 


\section{Sectoral Implementation of the Strategy:}

Aim 1 - Promote good governance, strengthen its effectiveness, and guarantee equity

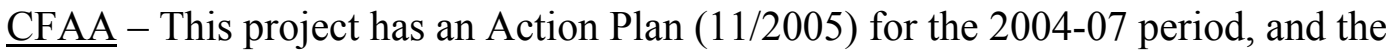
implementation of its priority measures has been coordinated by a CFAA implementation cell and monitored by the Steering Committee.

There is increasing cooperation between the FM Analysis Office and the CFAA project, with improved coordination for the implementation of the measures included in the Public Finance Reform action plan, as noted by our budget support partners. The quality of the implementation was recognized and rewarded by the Netherlands with an increase in funding and an extension in the implementation schedule.

In terms of rendering of accounts and reporting, there has been progress in the preparation of public accounts and general government accounts. The GGA for 2000-2002 were transmitted to Parliament (current practice) in 2005 as scheduled. The quarterly budget execution report is already available on the MFP website.

The Public Accounting Office has submitted a draft law for discussion among the various partners. Discussion and approval by the MFP had not occurred by late October 2005 as planned, pushing the approval by the Council of Ministers to 2006, when the new nomenclature will be implemented (and integrated into the SIGOF).

A set of financial actions and tools was developed and the implementation thereof provided for greater integration of the current information system, which is essential for sound management, control and quick decision making in budgeting and finance, with respect to budget and finance, assets, and contingencies.

Government Administration - The development of a modern and satisfactory image for Government Administration in the eyes of the user, with simplified and quick processes, is being carried out with the introduction of the appropriate information technology and the implementation of the "Citizen's Services Bureau." The start of renovations, equipment and staff training depends on the availability of funding.

The availability of the Citizen's Services Bureau and Cabo Verde Digital is an important factor for registering companies that wish to do business in Cape Verde.

The Strategic plan for State and Government Administration reform was prepared and validated and the document is available. This goal was achieved according to plan and meets the requirement of creation of an operational mechanism for public sector reform, including the political decision-making level, and the political policy-coordination and integration level.

In order to simplify public resource management processes, negotiations are underway to revise the Legislation on New Technologies. In terms of Information Society and egovernment, the e-government action plans (PAGE - Planos de Acção de Governação 
Electrónica) and the strategic plan for the Information Society (PESI - Plano Estratégico para a Sociedade de Informação) were developed and validated. The first steps have been taken to expand the State network to the national level.

The activities related to the drafting of legislation pertaining to the career of government administrator led to the production (09/30/05) of the final document: "Elaboração do plano de recrutamento/ selecção e formação dos novos administradores públicos" (Development of the New Government Administrator Recruiting/Selecting and Training Plan). A Government Administrator could not be placed in each government department in 2005. The process of obtaining funding to make the position of Government Administrator viable is a cause for concern.

There were no activities related to the study and review of the posts, careers and salaries plan (PCCS - plano de cargos, carreiras e salários) in 2005 even though this policy measure is considered to be fundamental to the process of capacity building, performance, mobility of skills, for the establishment of a high standard of services.

In order to ensure the decentralization of the Public Administration Database, a single database of human resources and salaries has been developed. This database is currently being harmonized and the computerized control of human resources and salaries will not be available before May 2006. Access to this database by the ministries, institutes, and enforcement organizations is scheduled for June 2006.

In order to rationalize the Structures of Government Administration, the INAG took preparatory steps for the development of an integrated plan for the areas of public administration, which produced a portfolio of training activities that have not yet been conducted due to lack of funding.

Justice - More agility, more coverage and the availability of conflict-resolution alternatives, particularly for those most in need of the justice system, as well as greater visibility and an improved image for justice were achieved through awareness-raising campaigns.

Aim 2 - Promote competitiveness in order to boost economic growth and job creation.

The "Crescimento e competitividade" (Growth and Competitiveness) project has been very satisfactory in promoting competitiveness according to the most recent mid-point progress evaluation. The greatest progress has been made in reducing bureaucracy, which is a result of the achievements of the NOSI and the Registry and Notary level programs. The telecommunications sector approved a very ambitious strategy in 2005.

On the legislative side, results have been mixed with regulation efforts. The Economic Regulation Agency (ARE - Agência de Regulação Económica) has been established and currently focuses its efforts on its mandate. One of its more significant achievements was the adoption of a tariff model to support decision-making in reestablishing a tariff balance. However, this matter is yet to be regulated. The recently established Food and Drug Regulation and Supervision Agency (ARFA - Agência de Regulação e Supervisão de Produtos Farmacêuticos e Alimentares) is still in the process of being installed (i.e., 
recruiting, organization, and funding). New telecommunications laws and regulations have been adopted. The overlap of ARE and ICTI (Institute) responsibilities for regulating the telecommunications sector was reduced with the adoption of a new law on electronic communications in November 2005. However, some overlap still remains.

The new Labor Code was completed and validated by the Social Harmonization Council at its December 2005 meeting and could not be promulgated by the end of the year. Legislation on commercial dispute arbitration and the related regulations were approved and the organizational structure, rules, and procedures are in discussion. Nineteen judges have been trained. The arbitration organizations were established at the Chambers of Commerce and are being properly equipped and staffed with the trained personnel (19). With respect to credit, the government, commercial banks, and the private sector are seeking means to improve and provided continued access to credit under reasonable conditions for small and medium-sized companies in order to increase their competitiveness. The volume of nonperforming loans at commercial banks has been reduced to 8 percent of their overall credit portfolio. This has occurred as a result of the BCV's supervision efforts and the commercial banks' collection and cancellation initiatives, which have improved consistently.

The acceleration of the registration (1-2 days) of companies that wish to do business in Cape Verde is in an initial phase. Cape Verde still has important requirements to fulfill before joining the World Trade Organization.

In terms of tourism promotion and development, one achievement is the Strategic Plan for Tourism Development, which has been translated from its original French version to Portuguese. No activities have been conducted under the Decentralized Tourism Promotion project. In terms of human resource capacity building, 63 individuals have been trained in environmental education and good environmental practices in the hospitality industry. At the central level, two DGT technical staff have been trained in tourism inspection.

\section{Aim 3 - Develop and enhance human capital.}

The development and enhancement of human capital puts emphasis on education. In other words, education takes on a key role in the implementation of the Strategy. Thus agent training and skills enhancement has benefited all educational levels given the strong correlation between level of instruction and poverty.

Education - The achievements at the pre-school level relate to expansion, on-the-job training, infrastructure development, inter-institutional coordination, and awareness-raising among families. Pre-school education continues to expand. The system currently covers 58.2 percent of children aged 3-5 years against 56 percent in 2004. The MEVRH has made efforts to provide pedagogical aids to teachers at this educational level. In 2005, 70 preschool teachers participated in a training event and 17 preschool coordinators received training in evaluating and supervising preschool educational activities. In light of the diversification of actors in the subsector (Municipalities, Government, NGOs, private entities, etc.), the greatest challenge is 
to adopt a National Preschool Children Policy to clarify the goals and objectives as well as the roles and responsibilities of each.

At the Basic Education level, the activities focused on teacher training, review of programs and textbooks, measures to reduce failure and drop-out rates, fostering of civic values such as peace, justice, etc., and infrastructure development. At the secondary level (SL), emphasis was given to strengthening teacher qualification, infrastructure development, curricular review, equipping of schools, revitalization of vocational schooling and its integration into professional training, educational and professional guidance in cooperation with employment centers, support for the private sector in developing the SL, and democracy in the management of secondary schools.

The effort to establish the University of Cape Verde is underway and has demonstrated the need to make the required resources available to rehabilitate, expand the infrastructure, and build capacity in the various institutes that will form the university.

With respect to youth and adult education, the activities were related to the reformulation and adaptation of curricula to include indigenous cultural values, and a post-literacy focus on jobcreation activities. Other special modes of schooling revolved around themes such as education for health, environment, family, population, citizenship, and gender-based approach.

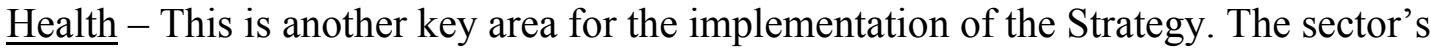
assessment highlights that most health programs operate according to routine and need to be closely monitored as to their outcomes.

The publication of vital statistics and data on diseases with mandatory disclosure, scope of services, vaccination coverage, and human resources is a necessary activity for a functional information system. Data is currently being gathered, processed, and analyzed. There is need for technical assistance in this area.

A strategic plan for human resources for the 2005-2014 period was developed in October 2004. However, the Ministry of Health has not yet prepared a multi-year action plan that adopts a systemic framework covering all providers (doctors, nurses, and technical staff).

The priorities in health programs are Maternal and Child Health, Vaccination, HIV/AIDS, and Tuberculosis. The area of infectious/contagious diseases has suffered delays in its achievements. Data continues to be gathered and is yet to be analyzed.

Social Protection and Security - A consultant was engaged in October 2005 to identify improvements for the information system in order to provide for better monitoring of the social security system and reduce fraud. The extension of coverage and the establishment of "special regimes" are being considered. Steps are being taken toward the creation of a community-based health insurance system in rural areas to improve access to health care and medications for rural populations. 
The new national population policy was validated in $12 / 2005$ and is beginning to be disseminated. Therefore, this goal was achieved. The final document is in the hands of the MFP and will be submitted to the Council of Ministers for approval. This new NPP is more operational and in greater conformity with the more recent population policy preparation methodologies.

The "Support for the National Population Policy" project provided technical and financial support for the academic research conducted by the finalists from the national institutions of higher education in the areas of population issues, development, and gender.

Aim 4 - Improve and develop basic infrastructures, promote land management, and conserve the environment.

The legislative framework for Land Management benefits from an extensive legislative package that includes the Land Use Law, the new Framework Land Management and Urban Planning Law, the Framework Land Registry Law, the Cartographic Production Law, and the Expropriation Law. This legislative package is in the hands of the Council of Ministers for validation. The rate of achievement was 100 percent. In addition, a new legislative package is being prepared, which includes the Leasing Law, the Condominium Law, the Real Estate and Land Development Law, and the General Regulation on Urban Construction. The regulation phase will follow.

Map production has already conducted several surveys in support of territorial and urban planning, based on a functional geographic/territorial information system and on human resource capacity building. In terms of rehabilitation and modernization of the national Geodetic Network, emphasis is given to the completion of the GPS Observations for planimetric coordinates, the calculation of "Transformation Coordinates," the launching of preparatory campaigns for "field completion" and other technical activities related to the collaboration with MUNICIPIA for the actual production of base maps (1:10,000 for the national territory; and 1:2,000 for 5,000 ha of urban areas). In addition, four field teams received on-the-job training and undertook an effort to reanalyze the National Geodetic Network.

The municipal land management plan and urban planning document development efforts include preliminary activities related to the launching of the Regional Land Management Scheme development process for Santiago, Santo Antão, and Fogo, as well as monitoring of TOR preparations for nine (9) Municipal Urban Plans. This project has suffered a delay.

In coordination with the municipalities, a preliminary phase is underway with the development of a new generation of Municipal Urban Plans in São Domingos, São Miguel, Santa Cruz, Tarrafal, Santa Catarina, Sal, Porto Novo, and other municipalities included in Municipal Development Plans (São Vicente and São Nicolau). Therefore, the schedule for the development of second-generation plans in the municipalities (Santa Catarina, Sal, Ribeira Grande, and São Miguel) selected in the PRSP was not met. 
The progress in setting up a National Land Registry System (SNC - Sistema Nacional de Cadastro) includes the drafting of the Framework Land Registry Law and a national Land Registration methodology. The methodology was tested and the conditions for the preparation of a Pilot Land Registry and the publication of a Procedures Manual in 2006 were established. The architecture adopted for the SNC requires the establishment of a Central Land Registry Service and Municipal Land Registry Cells that will proceed to the registration itself.

In terms of capacity building and as planned, two (2) high-level technicians from the DGOTH are enrolled in distance-learning master's programs. Training for 20 SIT technicians is yet to start. The level of implementation of this effort was not 100 percent.

Environment - In April 2005, the Netherlands and Cape Verde signed a Memorandum of Understanding related to budget support for $\mathrm{CV}$ in the amount of $€ 5$ million for the implementation of municipal and sectoral projects under PANA II for 2005. Of this amount, 60 percent will go to Municipal Environmental Plans (PAM - Planos Ambientais Municipais) and 40 percent to Intersectoral Environmental Plans (PAIS - Planos Ambientais Inter-Sectoriais).

Municipal Environmental Technical Teams (ETMA - Equipas Técnicas Municipais Ambientais) and Environmental Focal Points (PFA - Pontos Focais para o Ambiente): From November 2004 until March 2005, a technical team was installed in each municipality to coordinate PAM implementation. The sectoral Environmental Focal Points (PFA) have been designated. From November 2004 through January 2005, the relevant staff of the ETMA and the PFA received training on the preparation of activity plans and reports.

In March 2005, the PANA II Management and Monitoring Committee (composed of persons responsible for sectors, Institutes, Central Structure for Local Power Coordination, and the ANMCV, all involved in the PANA II) and the National Environmental Council (a government advisory organization for the environment) were established. The Committee met ordinarily in November and extraordinarily in December, and reviewed the PANA II implementation progress report.

The Municipalities' activities focused on environmental education, basic sanitation, and drinking water supply. Project implementation began in mid-year (July). According to the PAM monitoring reports (municipal and DGA), the impact from the implementation is positive and environmental quality improved considerably in the affected areas. The sectors gave priority to the continued implementation of projects related to creating the indicators listed in the budget support assessment. The DGA recruited 4 technical staff and restructured itself into three service directorates. Its Environmental IS is operational through the www.sia.cv portal.

In terms of institutions and implementation control, some difficulties were encountered in establishing a specific agency for the management of protected areas, which may affect the institutional strengthening of the DGA. Land use planning at the regional and municipal level was not accompanied by a legal frame of reference for controlling the implementation of land 
use plans nor by a requirement for construction licenses to be issued by the Municipalities. This may hurt the investment in planning land use and have a negative environmental and social impact. The Environmental Impact Assessment (EIA) lacks new EIA regulations. The Government's environmental policy should give priority to the involvement of different Public Administration sectors in this area.

The financial balance indicates an overall implementation rate of 59 percent (six months), 64 percent of which relates to the municipalities and 51.7 percent to the sectors.

There were enormous delays in the funding release mechanism, which prevented several projects from starting in 2005. This will result in the failure to attain some of the indicators established for 2005.

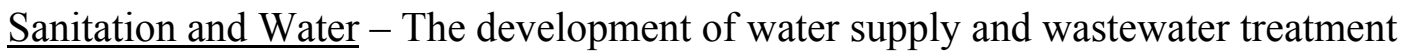
infrastructure is essential to increasing the rate of coverage for families served by the drinking water distribution and sewer network and with access to a solid waste collection system. The implementation activities focused essentially on urban areas. The outcomes include the installation and renovation of several kilometers of pipes (main, secondary, and tertiary) for drinking water distribution and connection to homes and public fountains; the drilling and equipping of several wells; the construction and rehabilitation of reservoirs; and the construction of public fountains as projects continued.

With respect to sanitation, several kilometers of main collectors were installed, pumping stations were built, and several kilometers of sewage pipes were installed. In S. Vicente alone, treated wastewaters are reused, thus allowing for the settlement of 50 farmers in 95 parcels of land in the agricultural perimeter thus built.

The details about the outcomes refer to an increase in water connections in Praia, from 22 percent in 2000 to 43.5 percent in 2005 , while the number of clients more than doubled, to almost 12,000 . The rate of home connections in S. Vicente reached 58.6 percent $(10,344$ customers) in 2005. The number of customers in Assomada in 2005 grew to almost 3,800, corresponding to a rate of 72.8 percent (34.6 percent in the Municipality). In Tarrafal, the number of customers rises to 2,750 in late 2005, corresponding to a connection rate of 86.6 percent (Village) and 57.1 percent (Municipality). In Sal, the connection rate stands at 50.6 percent (2,228 customers). In Boavista, the rate varied very little between 2000 and 2005 , remaining stable at 25.3 percent. In the municipality of Ribeira Grande, the coverage rate is 98 percent in urban areas and 55 percent in rural areas.

With respect to the projection that 50 percent of households will have access to drinking water, this objective has been reached in most urban centers. However, rural populations continue to be supplied mostly through public fountains, as the distribution networks were not expanded in an efficient manner.

With respect to the sewer network, only the cities of Praia and Mindelo have a functional wastewater treatment plant. Construction work started in November 2005 to allow secondary and tertiary treatments to be performed at Praia's ETAR, and should be completed by late 
2006. Wastewater treated at Praia's ETAR was being rejected for disposal at sea due to the lack of secondary and tertiary treatments. The treated water cannot be reused due to poor quality. The connection rate in Praia grew to 20 percent between 2000 and 2005 and may change shortly as a result of the ongoing project that is providing social connections to the network of water supply $(5,110$ homes) and sewers $(2,190)$. In S. Vicente, the rate of connection to the sewage network is higher, having reached 55 percent in 2005.

The general projection was that 2 percent of treated wastewater would be reused. This goal has not been reached due to the failure to build the sewage network and Assomadas's ETAR. In the municipality of Tarrafal, in Santiago, the Village's sewage network and ETAR were built 3 years ago but are still inoperable. There remain problems to be resolved, namely the implementation of home connections, the calculation of the cost for a home connection, the sanitation fee, properly trained personnel at the independent sanitation services, etc.

With respect to solid waste, the 40-percent coverage goal for the collection system was not reached. In general, solid waste collection systems are ineffective for lack of adequate equipment in terms of quantity and quality. This subsector is ripe with difficulties: the Vila de Tarrafal landfill is not operating and the S. Catarina deposit station operates inadequately. It is important to note that solid waste collection services are free.

The Action Items are included in the 3rd phase of Mindelo's sanitary plan and the city of Praia's water supply and Vila de Calheta's water supply project (all planned to start in the 2nd quarter of 2007). The second phase of the water supply for the city of Assomada does not have funding. The work should be financed by the IX FED and are estimated to cost about CVE 870 million. For the other municipalities and islands, there are no projects planned nor funding commitments for water supply in rural areas.

The sanitation aspect of the 3rd phase of the Sanitary Plan for Mindelo (estimated to cost CVE 760 million) and the city of Praia (estimated at CVE 340 million) should start in the 2nd quarter of 2007. The sanitation component (CVE 115 million) of Vila de Calheta's water supply project should begin in the 2nd quarter of 2007. The Kuwait Fund ensures funding for the implementation of the sewage network in Boavista and for S. Maria's ETAR on Sal Island. The project is estimated to cost CVE 400 million. As to Assomada, in light of the changes observed, it is recommended that the sanitation project be redesigned, which would require the procurement of new funding. There are no projects planned nor funding commitments for the other cases.

With funding provided under the IX FED, the "solid waste" component of the 3rd phase of Mindelo's Sanitary Plan (estimated to cost CVE 105 million) and Santiago's "Integrated Solid Waste Management" project (CVE 730 million) should begin in the 2nd quarter of 2007. There are no projects planned nor funding commitments for the other cases.

Several studies are in preparation and various project components are yet to be implemented in the area of water supply, sewage, and solid waste. For details, see the table annex pertaining to the Sanitation sector. 
Energy - In 2005, the energy sector development efforts resulted in a ....-percent power coverage rate for the population (70 percent on the grid) and a ....-percent rural electrification rate (70 percent on the grid). The National Renewable Energy Strategy was not designed and is planned for 2006. The first steps for an assessment of firewood and gas consumption and payment capacity were taken with the signing of a protocol with the INE for the survey, which will only be conducted in June 2006.

Aim 5 -Improve the social protection system, strengthen its effectiveness, and guarantee its sustainability.

In essence, the aim seeks to extend social protection system coverage for the population. In order to achieve it, a variable degree of progress has been obtained in the implementation of Social Protection, Integration, and Insertion (the planned actions are largely underway, others have been completed, and some are at an advanced stage of implementation) in terms of planning, management, decentralization, institutional capacity building, professional training, social housing, etc.

The activities undertaken to improve the planning and management tools resulted in the development of a multi-sectoral Strategy for Social Protection development and social risk management in Cape Verde. The outcomes are the detailed knowledge of the condition of social protection in the country (e.g., identification of agents and the universe of beneficiaries, ongoing programs, availability of resources, restrictions, and perspectives). The project cost rose to approximately 2.5 million escudos.

The Strategy includes a proposal to redefine the framework of public institutions responsible for coordinating and implementing the social protection policies, and the definition of a normative and institutional framework for public/private partnerships in this area, as well as implementation and monitoring mechanisms. Adequate institutional conditions are being established for the implementation of the strategy.

There is progress in pension system management, with the development of the Identification Card project for Beneficiaries of the Non-Contributing Regime. A reregistration was conducted among 13,882 beneficiaries (about 87 percent) both from the Social Solidarity Pension (PSS - Pensão de Solidariedade Social) and the Minimum Social Pension (PSM Pensão Social Mínima). The remaining 13 percent were not reregistered for lack of identification, dispersion, and difficulty of access to their residences. The implementation of this activity took longer than expected and cost around CVE 13.7 million.

The outcomes of the study on Pensions under the Non-Contributing Regime (funded by the World Bank through the Growth and Competitiveness Project) and the outcomes of the Identification Card project for Beneficiaries of the non-contributing regime include a detailed diagnostic of the pension system's current situation, a review of the planning and management tools, the creation of a database, the unification of the pensions under the noncontributing regime into a single pension (Social Pension), and the creation of a National Pension Center. 
A database was created, the Review Report was prepared, and a Social Atlas was produced as part of the Social Charter of Cape Verde project development (CVE 7.0 million). A website is planned, with more pertinent information about the Social Charter.

The decentralization of municipal Social Promotion services was reviewed. The decentralization will focus on facilitating municipal and local intervention to take the steps required to improve living conditions among the most underprivileged and to reduce poverty and social exclusion. The cost of this project was estimated at around CVE 3 million.

Activities are being carried out as part of a Support Program for students from poor families who do not benefit from scholarships, in order to extend access to education and training for underprivileged groups. This support provides help with academic, transportation, lodging, and other expenses domestically or abroad for a total of 212 students. This support grows to CVE 23.5 million during the 2004/2005 academic year.

The establishment of implementation protocols for (10) community projects with NGOs and Community Associations allowed coverage to be extended to nearly 1,150 direct beneficiaries (children and youth; disabled and/or at-risk children, the elderly, female heads of family, as well as some poor families and communities). This outcome follows the establishment of a Network of Community Intervention Agents for Poverty and Social Exclusion Reduction and capacity building for NGOs and Community Associations to fight poverty and marginalization. The total cost for this achievement reached CVE 15 million.

Various difficulties related to organization and coordination, lack of technical and human resources, and work conditions affected the implementation of some projects, particularly with respect to the established deadlines. In terms of joint-implementation projects, the inadequate coordination among the organizations is a source of some delay in their completion. In this regard, building institutional and organizational capacity in the sectors involved in the development of social protection policies continues to be a challenge.

\section{Protection of children's rights}

The outcomes include an inventory of NGOs working with the underaged. The list is available. However, this did not trigger any training session planning for these institutions. The availability of resources to build technical and material capacity at the transition centers for minors have been found to be inadequate.

Food security guarantee for the population - The activities that were undertaken in the area of food safety had the purpose of planning and ensuring the availability and stability of foodstuffs in the domestic market, the access thereto, their correct use, the effectiveness of the food crisis prevention and management mechanisms, as well as the institutional framework for FS, the plan, strategies, and programs for FS, and capacity building among the actors in accordance with the Food Security Strategy (approved in 2004), while the Action Plan for its implementation continues to be under preparation. 
In terms of planning, the five-year PNSA reformulation began on the basis of recommendations from a coordination panel convened in December 2005. The information on the country's nutritional situation is not available as the data gathered by the IDRF and in the survey on nutrition has not been analyzed yet.

With respect to the strengthening of the SIS, the Ministry of Agriculture and the Environment conducted a follow-up survey on food vulnerability among rural families in 2005 for the purpose of establishing a conceptual and methodological framework for the National Food Vulnerability and Insecurity Monitoring, Review, and Mapping Mechanism. The objective is twofold: to support decision-making and to contribute to the definition of policies and programs to combat food insecurity.

The exit of the World Food Program (WPF) from the "School Cafeteria" program leads the Government to identify ways to rationalize the program and ensure its long-term sustainability.

Despite the progress made in the local production of foodstuffs, Cape Verde cannot ensure food self-sufficiency in the medium term.

In terms of national food availability and stability, agricultural development is an important factor for the domestic market supply. ${ }^{1}$ The spread and dissemination of improved-race animals and the use of more adequate cattle-raising systems and techniques had an impact on the meat and milk supply and helped improve rural family income and diet.

The activities conducted by the various artisanal fisheries projects improved the organization of the sector and thus enhanced the domestic supply of fish, improved the population's diet, and enhanced the income of fishermen and fishmongers $(=10$ percent of the active population and 12 percent of the employed population).

The domestic supply based on imported foodstuffs is ensured essentially by private enterprises. The importation of food amidst an environment of market liberalization ${ }^{2}$ improved the supply of food (quantity, diversity, and price). But the quality of the supply continues to be inadequate.

With respect to the sanitary security and quality of the food supply, the situation is unsatisfactory. For this situation to improve, the Food and Drug Regulation and Supervision Agency (ARFA), established in 2004, must be functional. This agency continues to be installed and needs funding to stay operational in the short term.

\footnotetext{
${ }^{1}$ The average annual growth in horticultural production was 14 percent. The annual production is estimated at $12,500-13,000 \mathrm{t}( \pm 50$ percent $=$ bananas $)$.

${ }^{2}$ Market liberalization led to the privatization of MOAVE and the winding up of EMPA, as well as the takeover of the market supply by private enterprises and the establishment of the ANSA.
} 
The food aid entering ${ }^{3}$ the country plays an important role in the country's grain supply and has represented, on average, approximately 38 percent of grain imports in the last four (4) years.

Access to adequate nutrition has been provided to a significant number of needy families and poor farmers through the National Poverty Reduction Program activities as well as the food aid provided by public and private organizations to the disadvantaged and at-risk populations. The vehicles used are the assistance program for vulnerable groups and to the WPF-supported school cafeteria program. These same organizations also conduct social promotion and protection activities consisting of monetary assistance, health care services, payment of a Minimum Social Pension, and access to basic social programs for different groups of the population at risk to fill temporary or permanent needs.

The Minimum Social Protection (PSM - Protecção Social Mínima) and the Social Solidarity Pension (PSS - Pensão de Solidariedade Social) ensure such health care as well as access to basic social programs and said pensions.

The fight against malnutrition and awareness-raising regarding the correct use of food have progressed with the systematic distribution of ferrous sulfate to pregnant women, nutritional education activities among the population, iodization of salt for human and animal consumption, campaigns to promote exclusive breastfeeding of children up to 4-6 months and extended to 2 years, and the supply of micronutrient supplements (iron and vitamin A) to the higher-risk groups, as well as the quality improvements introduced in the monitoring and evaluation of growth and development among children younger than 5 years of age and pregnant women at healthcare providers.

With respect to the crisis prevention and management mechanisms, a follow-up survey was conducted in 2005 on food vulnerability among rural families, which included close to 4,400 families, for the purpose of establishing a conceptual and methodological framework for the National Food Vulnerability and Insecurity Monitoring, Review, and Mapping Mechanism for rural areas).

In 2005, the DSSA published a newsletter entitled "Crop Year 2004/05: Impact on Food Security Conditions for Rural Families on the Main Agricultural Islands." This newsletter is available in printed format and is described on the National Statistics Institute website (www.ine.cv).

The policies and programs that guide the handling of FS issues are described in the 2006-2010 National Food Security Program (PNSA 2006-2010 - Programa Nacional de Segurança Familiar). This is based on food security policy orientations contained in the 2015 National Food Security Strategy (ENSA 2015 - Estratégia Nacional de Segurança Familiar), in the 2015 Agricultural Development Strategy (EDA 2015 - Estratégia de Desenvolvimento Agrícola), in the 2004-2007 Poverty Reduction Strategy Paper (PRSP 2004 -

\footnotetext{
${ }^{3}$ The Counterpart Funds (Year 2005) generated by the sale of food aid reached a net total of CVE 101,027,150.
} 
2007), etc. Moreover, they leverage the lessons learned with the Special Food Security Program (PESA - Programa Especial de Segurança Alimentar), which was funded by the FAO, the ADB and the Government, and implemented between 1997 and 2005.

Food security is covered by the 2nd three-year phase of the National Food Security Program, which began in 2005. The purpose of the activities is to improve the formulation and impact of policies and programs in the area of food security. The cost for this phase is estimated at US\$284,295. Another objective is to develop a Medium-Term Investment Plan for financial management and implementation monitoring for PNSA projects.

The "Food Security Santiago" and other projects were carried out in 2005 in order to build FS capacity (planning, management, intervention) among illiterate female heads of family in rural areas of different municipalities on Santiago Island. The universe of beneficiaries was extended to other groups according to the existing conditions in the areas of intervention. The project benefited a total of 111 families.

Interim difficulties - The means turned out to be insufficient to implement public policies in the area of food security. It is regrettable that the beneficiaries' involvement in the implementation of the actions is still limited. The implementation of the actions in the area of FS requires intersectoral coordination and harmonization in order to maximize the impact on the target populations. Harmonization and coordination turned out to be a difficult exercise. Yet, the outcomes from the actions include improvements in food security conditions for families (availability and access). The balanced use of foods continues to be inadequate and in need of more focused actions.

Adjustment and Redefinition of Housing Promotion - The activities in the area of housing promotion were implemented only partially, through the Operação Esperança (Operation Hope) program, for various reasons, especially the limited availability of technical and human resources. 


\begin{tabular}{|c|c|c|c|}
\hline SECTOR & Situation as of 2004 or Another Date & Execution Outcome & Situation in 2005 \\
\hline \multirow{4}{*}{$\begin{array}{l}\text { Water Supply and } \\
\text { Distribution } \\
\text { Infrastructure }\end{array}$} & PRAIA: 5,311 residential customers in 2000 & PRAIA: $128,166 \mathrm{~m}$ of various pipelines installed & 11,889 residential customers, or $43.5 \%$ with \\
\hline & $\begin{array}{l}\text { MINDELO: } 7,970 \text { residential customers in } 2000 \text {, or a } 51 \% \\
\text { connection rate }\end{array}$ & $\begin{array}{l}\text { S. VICENTE: Study of Phase III of Mindelo } \\
\text { Sanitation Plan in preparation }\end{array}$ & $\begin{array}{l}10,344 \text { residential customers, or a } 58.6 \% \\
\text { connection rate }\end{array}$ \\
\hline & $\begin{array}{l}\text { ASSOMADA: } 1,728 \text { residential customers in } 2002, \text { or a } 69 \% \\
\text { connection rate; Township: connection rate }=17.1 \%\end{array}$ & $\begin{array}{l}\text { ASSOMADA: } 19,393 \mathrm{~m} \text { of various pipelines } \\
\text { installed }\end{array}$ & $\begin{array}{l}\text { ASSOMADA: } 3,793 \text { customers, or a } 72.8 \% \\
\text { connection rate; Township: connection rate }= \\
34.6 \%\end{array}$ \\
\hline & $\begin{array}{l}\text { 1,367 customers (2001); TARRAFAL Village: connection rate } \\
=73.8 \% \text {; Township: connection rate }=33.8 \% \text { in } 2002\end{array}$ & $\begin{array}{l}\text { TARRAFAL: } 24,974 \mathrm{~m} \text { of various pipelines } \\
\text { installed }\end{array}$ & $\begin{array}{l}\text { TARRAFAL Village: } 2,750 \text { customers, or an } 88.6 \% \\
\text { connection rate; Township: connection rate }= \\
57.1 \%\end{array}$ \\
\hline \multirow{6}{*}{$\begin{array}{l}\text { Water Supply and } \\
\text { Distribution } \\
\text { Infrastructure }\end{array}$} & $\begin{array}{l}\text { ILHA DO SAL: } 1,944 \text { residential customers (2000); } \\
\text { connection rate }=47 \%\end{array}$ & Pipelines installed and storage facilities built & $\begin{array}{l}\text { ILHA DO SAL: } 2,228 \text { residential customers, or a } \\
50.6 \% \text { connection rate }\end{array}$ \\
\hline & SAL REI - BOAVISTA: 264 residential customers (2000); & Pipelines installed and storage facilities built & 353 residential customers, or a $25.3 \%$ connection \\
\hline & $\begin{array}{l}774 \text { residential customers }(2004) \text {; connection rate }=75 \% \text { in } \\
\text { PEDRA BADEJO for the localities of Porto Abaixo, Porto } \\
\text { Acima, and Achada Fátima. For the localities of Salina and } \\
\text { Ponta Achada: no. of customers }=175 ; \text { connection rate = } \\
39 \% \text {. } \\
\text { Achada Fazenda: no. of customers }=65 ; \text { connection rate }= \\
14 \% \\
\text { Achada Igreja: no. of customers }=107 ; \text { connection rate }= \\
100 \%\end{array}$ & Pipelines installed and storage facilities built & Extension of the water supply network is planned. \\
\hline & $\begin{array}{l}\text { PONTA DO SOL, RIBEIRA GRANDE, and PAÚL: 1,323 urban } \\
\text { customers and 1,235 rural customers (2003) -> RIBEIRA } \\
\text { GRANDE TOWNSHIP }\end{array}$ & Pipelines installed and storage facilities built & $\begin{array}{l}1,390 \text { urban customers ( } 98 \% \text { coverage) and } 2,008 \\
\text { rural customers ( } 55 \% \text { coverage) -> RIBEIRA } \\
\text { GRANDE TOWNSHIP }\end{array}$ \\
\hline & PORTO NOVO - S. ANTÃO - June 2001 & $\begin{array}{l}32,250 \mathrm{~m} \text { of pipes installed and a } 200 \mathrm{~m} 3 \\
\text { reservoir built }\end{array}$ & \\
\hline & $\begin{array}{l}\text { NATIONWIDE: } 25 \% \text { of households connected to the drinking } \\
\text { water distribution network }\end{array}$ & $\begin{array}{l}\text { Doubling of household access to the water } \\
\text { supply network }\end{array}$ & $\begin{array}{l}50 \% \text { of households connected to the drinking } \\
\text { water distribution network }\end{array}$ \\
\hline \multirow{4}{*}{$\begin{array}{l}\text { Residual Water } \\
\text { Collection and } \\
\text { Treatment } \\
\text { Infrastructure }\end{array}$} & \multirow[t]{2}{*}{$\begin{array}{l}\text { TOWN OF PRAIA: } \\
\text { Sewer system connection rate in } 2000: 8 \%\end{array}$} & $\begin{array}{l}3,390 \mathrm{~m} \text { of main sewage collector installed; } 2 \\
\text { pumping stations built and } 26,191 \mathrm{~m} \text { of sewer } \\
\text { svstem installed }\end{array}$ & Sewer system connection rate: $20 \%$ \\
\hline & & $\begin{array}{l}\text { Contract begun in November } 2005 \text { for } \\
\text { secondary and tertiary treatment at PRAIA } \\
\text { residual water treatment station }\end{array}$ & Works in progress \\
\hline & $\begin{array}{l}\text { TOWN OF MINDELO: Sewer system connection rate in } 1999 \\
\text { was } 38 \% \text {. }\end{array}$ & $\begin{array}{l}\text { Repair and reuse of MINDELO residual water } \\
\text { treatment station }\end{array}$ & $\begin{array}{l}\text { The project was completed in the first half of } \\
2005 \text {. The sewer system connection rate is 55\%. }\end{array}$ \\
\hline & Households with access to the sewer system $=11.5 \%$ & $\begin{array}{l}\text { Very significant increase in the number of } \\
\text { households with access to the sewer system }\end{array}$ & $\begin{array}{l}\text { Households with access to the sewer system }= \\
30 \%\end{array}$ \\
\hline
\end{tabular}


GLOBAL SUMMARY OF PRSP IMPLEMENTATION - 2005 - HEALTH SECTOR

\begin{tabular}{|c|c|c|c|}
\hline SECTOR & $\begin{array}{l}\text { Situation as of } 2004 \text { or Another } \\
\text { Date }\end{array}$ & Execution Outcome & Situation in 2005 \\
\hline \multirow[t]{2}{*}{$\begin{array}{l}\text { HEALTH (rehabilitation and } \\
\text { equipping of health facilities) }\end{array}$} & $\begin{array}{l}\text { Access to health facilities provided to } \\
35 \% \text { of the population }\end{array}$ & Significant improvement in access to health & $\begin{array}{l}\text { Access to health facilities provided to } 47 \% \text { of } t \\
\text { population }\end{array}$ \\
\hline & $\begin{array}{l}\text { Preparation of the multiyear vaccination } \\
\text { plan; 7_\% of children under one year of } \\
\text { age were completely vaccinated in } \\
2004 .\end{array}$ & $\begin{array}{l}\text { Increase in the number of children completely } \\
\text { vaccinated; updated information on vaccinal coverage in } \\
\text { Cape Verde's various townships }\end{array}$ & $\begin{array}{l}\text { Eighty percent of children under one year of at } \\
\text { completely vaccinated in 2005. The report on } 1 \\
\text { vaccinal coverage assessment survey was avai }\end{array}$ \\
\hline $\begin{array}{l}\text { HEALTH (implementation } \\
\text { of the National Health } \\
\text { Information System } \\
\text { Action Plan) }\end{array}$ & $\begin{array}{l}\text { Quarterly rate of notification of } \\
\text { tuberculosis cases }=59 \% \text { in } 2003\end{array}$ & $\begin{array}{l}\text { Current stock of medicines; health units detect HIV/AIDS } \\
\text { in tuberculosis carriers and provide counseling to them. }\end{array}$ & $\begin{array}{l}\text { Increase in the quarterly rate of notification of } \\
(88.2 \% \text { in } 2005) \text {; quality of bacteriological dia: } \\
\text { rose to } 68.1 \% \text {; laboratories had limited capaci } \\
\text { evaluating diagnostic quality; existence of dic } \\
\text { only cases. }\end{array}$ \\
\hline \multirow{3}{*}{$\begin{array}{l}\text { HEALTH (priority } \\
\text { programs) }\end{array}$} & \begin{tabular}{|l|} 
Approximately 3,000 persons per year \\
were voluntarily tested for HIV/AIDS. \\
The prevalence rate among pregnant \\
women was $0.44 \%$ ( 2004 sentinel \\
posts). The coverage rate among \\
patients evaluated for ARV treatment in \\
the first year was $30 \%$ (projected: \\
$10 \%-15 \%$ ).
\end{tabular} & $\begin{array}{l}\text { Offer of antiretroviral (ARV) treatment; enhanced training } \\
\text { of laboratory technicians in determining viral load, } \\
\text { definition of priorities, and preparation of the Fourth } \\
\text { Strategic Plan in the framework of the Program to } \\
\text { Combat HIV/AIDS }\end{array}$ & $\begin{array}{l}\text { Eight thousand persons per year were voluntal } \\
\text { tested, } 148 \text { persons were receiving antiretrovil } \\
\text { treatment, and } 15 \text { pregnant women were enro } \\
\text { the vertical transmission prevention program. } \\
\text { Behavioral data were available from the Secon } \\
\text { Demographic and Reproductive Health Survey. } \\
\text { HIV/AIDS prevalence rate among pregnant wo } \\
\text { receiving care was } 1 \% \text {. }\end{array}$ \\
\hline & $\begin{array}{l}\text { Reproductive Health Program in } \\
\text { execution }\end{array}$ & $\begin{array}{l}\text { Start of execution of the Reproductive Health Program } \\
\text { strategy; demographic and reproductive health survey } \\
\text { completed }\end{array}$ & $\begin{array}{l}\text { Supervision of reproductive health and other } h \\
\text { services for adolescents in Praia, Mindelo, and } \\
\text { data from the Second Demographic and Repro } \\
\text { Health Survey were being analyzed along with } \\
\text { information on program impact. }\end{array}$ \\
\hline & $\begin{array}{l}\text { Maternal mortality rate: } 7.6 \text { per } \\
100,000 \text { live births }\end{array}$ & & \\
\hline $\begin{array}{l}\text { HEALTH (human } \\
\text { resources planning and } \\
\text { management) }\end{array}$ & & $\begin{array}{l}\text { Obstetrical nursing course has been completed. Training } \\
\text { in specialized medicine is continuing. General nursing } \\
\text { course and supervision of new health professionals have } \\
\text { been initiated. }\end{array}$ & $\begin{array}{l}\text { New health technicians were recruited: } 100 \mathrm{nu} \\
\text { doctors, and } 6 \text { other advanced technicians. Fin } \\
\text { resources were insufficient to support fellowsh } \\
\text { abroad. }\end{array}$ \\
\hline HEALTH vs. BUDGET & $\begin{array}{l}\text { Health expenditures represented } 8.1 \% \\
\text { of the government budget in } 2004 \text {. }\end{array}$ & $\begin{array}{l}\text { Health expenditures reached } 8.2 \% \text { of the government } \\
\text { budget. }\end{array}$ & $\begin{array}{l}\text { Health expenditures represented } 8.2 \% \text { of the } \\
\text { government budget. }\end{array}$ \\
\hline
\end{tabular}


GLOBAL SUMMARY OF PRSP IMPLEMENTATION - 2005 - EDUCATION SECTOR

\begin{tabular}{|c|c|c|c|}
\hline SECTOR & $\begin{array}{l}\text { Situation as of } 2004 \text { or Another } \\
\text { Date }\end{array}$ & Execution Outcome & Situation in 2005 \\
\hline \multirow{5}{*}{$\begin{array}{l}\text { EDUCATION (primary } \\
\text { education) }\end{array}$} & 11.4\% REPETITION RATE & $0.2 \%$ REDUCTION & 11.2\% REPETITION RATE \\
\hline & $90 \%$ primary education completion rate & $1 \%$ increase & $91 \%$ primary education completion rate \\
\hline & $\begin{array}{l}83.2 \% \text { enrollment rate in the first year } \\
\text { of secondary education }\end{array}$ & $2.8 \%$ increase & $\begin{array}{l}86 \% \text { enrollment rate in the first year of seconc } \\
\text { education }\end{array}$ \\
\hline & $\begin{array}{l}\text { Primary education teachers with } \\
\text { professional qualifications }=27.3 \%\end{array}$ & Slight deterioration in the situation & $\begin{array}{l}\text { Primary education teachers with professional } \\
\text { qualifications }=22.1 \%\end{array}$ \\
\hline & $\begin{array}{l}\text { Three-year training plan for primary } \\
\text { education teachers being developed }\end{array}$ & $\begin{array}{l}\text { Three-year training plan for primary education teachers } \\
\text { developed }\end{array}$ & $\begin{array}{l}\text { In the first year of the training plan (2005), } 6 \\
\text { primary education teachers were trained as pli } \\
\text { (information from the Pedagogical Institute). }\end{array}$ \\
\hline \multirow{3}{*}{$\begin{array}{l}\text { EDUCATION (secondary } \\
\text { education) }\end{array}$} & $\begin{array}{l}\text { Fifty-nine percent of students } \\
\text { completed eight years of schooling. }\end{array}$ & Slight improvement & $\begin{array}{l}\text { Sixty percent of students completed eight year } \\
\text { schooling. }\end{array}$ \\
\hline & $\begin{array}{l}\begin{array}{l}\text { Students registered in secondary } \\
\text { technical education }=4.6 \%\end{array} \\
\end{array}$ & Slight improvement & $\begin{array}{l}\text { Students registered in secondary technical edı } \\
5 \%\end{array}$ \\
\hline & \begin{tabular}{|l|}
$\%[\mathrm{sic}]$ of teachers with adequate \\
training and others in advanced training
\end{tabular} & & $\begin{array}{l}60 \% \text { of teachers with adequate training; } 22 \% \\
\text { teachers in advanced training }\end{array}$ \\
\hline $\begin{array}{l}\text { EDUCATION - SOCIAL } \\
\text { ACTION IN THE SCHOOLS }\end{array}$ & & $\begin{array}{l}\text { Lunch and a hot meal provided in the schools; } \\
\text { cafeterias/stores operating; transportation of pupils; } \\
\text { scholarships and school supplies granted to pupils. }\end{array}$ & $\begin{array}{l}\text { A lunch and a hot meal were provided to } 100, \\
\text { children. Seven cafeterias/stores were built, } \\
\text { rehabilitated, and equipped. Transportation we } \\
\text { provided to } 2,214 \text { pupils, } 534 \text { pupils received } \\
\text { scholarships, and } 11,935 \text { pupils received schoc } \\
\text { sunnlies. }\end{array}$ \\
\hline EDUCATION - LITERACY & & $\begin{array}{l}\text { Publication of teaching materials; various kinds of } \\
\text { training }\end{array}$ & $\begin{array}{l}\text { In the first phase, } 4,500 \text { copies of the literacy } \\
\text { and } 3,500 \text { copies of the mathematics manual } \\
\text { published. Information was provided to } 5,261 \\
\text { in the context of the National Antipoverty Plan } \\
\text { Microproject training was provided to } 197 \text { yout } \\
\text { S. Catarina and } 141 \text { from Tarrafal. } \\
\end{array}$ \\
\hline EDUCATION vS. BUDGET & $\begin{array}{l}\text { Total education expenditures } \\
\text { represented } 31 \% \text { of the government } \\
\text { budget in } 2004 .\end{array}$ & & $\begin{array}{l}\text { Education expenditures represented } 29 \% \text { of th } \\
\text { government budget. }\end{array}$ \\
\hline
\end{tabular}




\begin{tabular}{|c|c|c|c|}
\hline SECTOR & $\begin{array}{l}\text { Situation as of } 2004 \text { or Another } \\
\text { Date }\end{array}$ & Execution Outcome & Situation in 2005 \\
\hline \multirow{7}{*}{$\begin{array}{l}\text { Social Protection, } \\
\text { Integration, and Insertion } \\
\text { (improvement of planning } \\
\text { and management tools - } \\
\text { improved management of } \\
\text { non-contributory pension } \\
\text { scheme and enlargement } \\
\text { of the universe of } \\
\text { beneficiaries) }\end{array}$} & & Social Map of Cape Verde prepared and disseminated & Social Map website created; Social Map applied to social programs \\
\hline & & Database created and implemented & \\
\hline & & $\begin{array}{l}\text { Conduct of a study of non-contributory pension schemes (PSM and PSS): } \\
\text { study conducted and disseminated }\end{array}$ & $\begin{array}{l}\text { Report on the project "Identification card for beneficiaries of the } \\
\text { non-contributory pension scheme" }\end{array}$ \\
\hline & & \begin{tabular}{|l|} 
Beneficiary database created \\
\end{tabular} & Beneficiary database operational \\
\hline & & Card issued to beneficiaries of the non-contributory pension scheme & Organization of candidates for social pension continuing \\
\hline & & Legal provision unifying the non-contributory pension schemes enacted & Decree-Law unifying non-contributory pension schemes \\
\hline & & $\begin{array}{l}\text { Preparations for establishment of National Pension Center - National } \\
\text { Pension Center established and operating }\end{array}$ & National Pension Center and mutual-benefit fund established \\
\hline \multirow{3}{*}{$\begin{array}{l}\text { Social Protection, } \\
\text { Integration, and Insertion } \\
\text { (PENSÕES) }\end{array}$} & $\begin{array}{l}\text { 6,514 beneficiaries of the Minimum } \\
\text { Social Pension (PSM) }\end{array}$ & Increase in the amount allocated (PSM) from $\$ 1,300$ to $\$ 3,0000$ & Social Solidarity Pension beneficiaries $=7,514$ \\
\hline & $\begin{array}{l}9,373 \text { beneficiaries of the Social } \\
\text { Solidarity Pension (PSS) }\end{array}$ & Significant increase in the number of beneficiaries and increase in the & Social Solidarity Pension beneficiaries $=11,427$ \\
\hline & & & $\begin{array}{l}\text { Ten percent of the population was covered by a social protection } \\
\text { system. }\end{array}$ \\
\hline
\end{tabular}


Sorry—content unavailable; section/page intentionally left blank

GLOBAL SUMMARY OF PRSP IMPLEMENTATION - 2005 - PUBLIC ADMINISTRATION SECTOR

\begin{tabular}{|c|c|c|c|}
\hline SECTOR & \begin{tabular}{|l|} 
Situation as of 2004 or Another \\
Date
\end{tabular} & Execution Outcome & Situation in 2005 \\
\hline \multirow[t]{3}{*}{$\begin{array}{l}\text { Public Administration } \\
\text { Reform and Modernization }\end{array}$} & & $\begin{array}{l}\text { Architectural study for remodeling of the physical space } \\
\text { and launch of the first Cape Verde Citizen House: } \\
\text { competitive bid held and candidates selected } \\
\begin{array}{l}\text { Amendment of the laws on new technologies has helped } \\
\text { to simplify public resource management procedures. }\end{array}\end{array}$ & Remodeling works dependent on commitments \\
\hline & & $\begin{array}{l}\text { Preparation of a study on creating an operational } \\
\text { mechanism for public sector reform } \\
\text { Formulation of a program to ensure decentralization of } \\
\text { the public administration database }\end{array}$ & $\begin{array}{l}\text { Interministerial Commission on Government R, } \\
\text { operational; study validated } \\
\text { Database concentrated in Government Accoun } \\
\text { consolidation of salaries and human resources; } \\
\text { and assimilation of human resources database }\end{array}$ \\
\hline & & $\begin{array}{l}\text { Action Plan for Electronic Governance and Strategic Plan } \\
\text { for the Information Society (PESI) developed and } \\
\text { presented at a forum; PESI validated in 2005; } \\
\text { Interministerial Commission for the Information Society } \\
\text { created } \\
\text { Integrated Training Plan for Public Management Areas } \\
\text { completed } \\
\text { Analysis and revision of the Job, Career, and Salary }\end{array}$ & $\begin{array}{l}\text { Training portfolio prepared } \\
\text { Assimilation of human resources database rear }\end{array}$ \\
\hline
\end{tabular}


GLOBAL SUMMARY OF PRSP IMPLEMENTATION - 2005 - ENERGY SECTOR

\begin{tabular}{|l|l|l|l}
\hline \multicolumn{1}{|c|}{ SECTOR } & $\begin{array}{l}\text { Situation as of 2004 or Another } \\
\text { Date }\end{array}$ & Execution Outcome & Situation in 2005 \\
$\begin{array}{l}\text { ENERGY (Acess to an } \\
\text { energy source) }\end{array}$ & $\begin{array}{l}\text { Households with access to electricity = Significant increase in household coverage } \\
58.5 \%\end{array}$ & Household electrification coverage = 70\% \\
\hline
\end{tabular}

